efektyvnosti vyrobnychogho pidpryjemstva. Stefanyka, 2014, no. 1(23), pp. 330-340 (in Problemy ekonomiky, 2014, no. 4, pp. 262-268 Ukrainian)

(in Ukrainian)

8 Ovjechkina O. A., Solokha D. V.,

7 Rusyn P.C Metody optymizaciji Ivanova K. V., Morjeva V. V., Bjeljakova O. tovarnogho asortymentu pidpryjemstva V., Balakaj O. B. Planuvannja marketynghu. Modeljuvannja reghionaljnoji ekonomiky. 2-ghe vyd. pererob. ta dop.: navch. posib. K.: Zbirnyk naukovykh pracj. Ivano-Frankivsjk: «Centr uchbovoji literatury», 2013. 352 p (in Vydavnyctvo «Plaj» CIT PNU im. V. Ukrainian)

УДК: 658.114:656.07

\title{
РЕСУРСИ СТИВІДОРНОЇ КОМПАНІЇ ЯК ОБ'ЄКТ КОНТРОЛІНГУ
}

\author{
Онешко С.В., к.е.н., доцент, \\ Зданевич Д.А., магістр (ОНМУ)
}

В статті розглянуті теоретичні та практичні аспекти впровадження системи контролінгу в діяльність стивідорної компанії, визначені особливості формування ї̈ ресурсів. Особлива увага приділена оцінці ресурсів компанії на базі ключових показників ефективності, використання яких дозволяе критично оцінити продуктивність, оперативність, якість або витрати. Запропоновано алгоритм та перелік ключових показників ефективності використання ресурсів стивідорної компанії, які враховують особливості ї̈ діяльності, оцінка яких сприяє економічному зростанню та ефективності розвитку.

Ключові слова: контролінг, об’єкти контролінгу, ресурси, ключові показники ерективності, стивідорна компанія.

\section{РЕСУРСЫ СТИВИДОРНОЙ КОМПАНИИ КАК ОБЪЕКТ КОНТРОЛЛИНГА}

\author{
Онешко С.В., к.э.н., доцент, \\ Зданевич Д.А., магистр (ОНМУ)
}

В статье рассмотрены теоретические и практические аспекты внедрения системь контроллинга в деятельность стивидорной компании, определень особенности формирования ее ресурсов. Особое внимание уделено оценке ресурсов компании на базе ключевых показателей эффективности, использование которых позволяет критически оченить производительность, оперативность, качество или затраты. Предложен алгоритм и перечень ключевых показателей эффективности использования ресурсов стивидорной компании, учитывающче особенности ее деятельности, аналіз которых способствует экономическому росту и эффективности развития.

Ключевые слова: контроллин, объекты контроллинга, ресурсы, ключевые показатели эффективности, стивидорная компания. 


\title{
RESOURCES OF THE STEVEDORING COMPANY AS AN OBJECT OF CONTROLLING
}

\author{
Oneshko S.V., PhD in Economics, Associate Professor, \\ Zdanevich D.A., Master (ONMU)
}

The purpose of the research is to determine the algorithm of evaluation and composition of key indicators of use efficiency of stevedoring company resources in the controlling system. When researching the resources of a stevedoring company, it is necessary to take into account the specifics of its activity: product is a service that cannot be stored and accumulated; material resources do not participate in the creation of finished goods in the form of inventory; in the formation of financial resources, all financial indicators are pledged through the forecast dollar exchange rate and when calculating this rate does not always meet the forecast; the income of the stevedoring company is based on revenue from the stevedoring services; there are no transport, storage and packaging costs when generating marketing costs, for the most part, these costs consist of advertising costs. In the controlling system, the company's resources are evaluated on the basis of Key Performance Indicators (KPIs), the use of which can critically evaluate the productivity, efficiency, quality or costs of the company. Using the recommended KPIs, you can evaluate the effectiveness of the process, draw conclusions about the potential and get recommendations for the necessary changes. There are the following types of KPIs: absolute and relative; quantitative and qualitative; input- and output-oriented or effectoriented. Relative KPIs have advantages that are suitable for benchmarking purposes. The algorithm of estimation and the list of key indicators of use efficiency of stevedoring company resources in the controlling system are offered, which takes into account the presence of different types of deviations and is aimed at performing the main functions of controlling: accounting and control (comparison of planned and actual indicators) and prevention (risk prevention). The use of the proposed KPIs is based on the analysis and diagnosis of the processes and factors impact in connection with business activities and will allow for a continuous process of monitoring and recording the planned and actual parameters of the stevedoring company to track the dynamics of change for each type of resources to improve efficiency.

Key words: controlling, objects of controlling, resources, key performance indicators, stevedoring company.

Постановка проблеми. У ринкових умовах, які характеризуються високою невизначеністю та нестабільністю зовнішнього середовища, посиленням конкурентних відношень на світових та вітчизняних ринках, ефективне управління передбачає великий обсяг планової та контрольної роботи. Невід'ємною частиною сучасної системи управління підприємством $\epsilon$ контролінг, який $є$ зворотним зв'язком управління, а об'єкти контролінгу, як управлінські інструменти, об'єднують спосіб управління та відповідний методичний інструментарій. Об'єктами контролінгу $€$ фактори виробництва, процеси, показники ефективності їх використання та організації, потенціал підприємства (чисельність, основні засоби, потужність, обсяг виробництва i збуту тощо), а також показники фінансового стану у порівнянні з прогнозованими.

Головну роль в забезпеченні стабільного функціонування суб'єкта господарювання відіграють різні види ресурсів, від яких напряму залежать результати діяльності, а наявність, якість та взаємодія відповідних видів ресурсів $\epsilon$ запорукою їх ефективного використання. В процесі використання ресурси відносяться

Вісник економіки транспорту і промисловості № 67, 2019 
на різні види витрат, що напряму впливає на формування фінансового результату.

В процесі здійснення фінансовогосподарської діяльності показники, закладені в фінансовий план стивідорних компаній, переважно можуть суттєво змінитися. Оперативне порівняння планових і фактичних значень ключових показників 3 метою виявлення їх взаємозалежності $€$ ключовим принципом концепції контролінгу або «управління за відхиленнями».

Аналіз останніх досліджень i публікацій. Трактування терміну «контролінг» у літературних джерелах неоднозначно та має принципові відзнаки. Неоднозначність у визначенні контролінгу можливо пояснити тим, що його розвиток відбувався впродовж тривалого часу, протягом якого він видозмінювався, а також відмінністю моделей по відношенню теоретичних досліджень та практичного використання.

Загальні теоретичні засади контролінгу викладені у роботах В. Бекера [1], Р. Манна, Э. Майера [2], Д. Хана, Х. Хунгенберга [3].

Міжнародною групою контролінгу (IGC) створена концепція контролінгу, що підтримується на міжнародному рівні, сформульовані професійні компетенції контролера, визначені: місія контролера, модель процесу управління, ключові показники ефективності (KPI) вимірювання продуктивності в процесу контролінгу та ін. [4].

Науковцями, які досліджували контролінг 3 різних аспектів для підприємств портової діяльності, встановлені: формат впровадження контролінгової системи $[5,6]$, доцільність впровадження інструментів контролінгу тарифів та ставок портових зборів [7, 8, 9], система управління економічною безпекою на базі системи контролінгу [10]. Контрольний аспект здійснення фінансового моніторингу підприємств портової галузі на базі ризик-орієнтованого підходу викладено у роботі [11].
Виділення невирішених частин загальної проблеми. $\mathrm{y}$ світовій та вітчизняній теорії та практиці не існує єдиної точки зору щодо сутності контролінгу. Невизначеність сутності контролінгу, насамперед, пов'язана з тим, що концепція контролінгу не містить нових знань 3 економіки підприємства, а лише використовує інструментарій інших дисциплін. Дійсно, контролінг - це складне синтезоване поняття, яке грунтується на наукових досягненнях різних дисциплін менеджменту, бухгалтерського обліку, економічної теорії, економічного аналізу, маркетингу, соціології.

Впровадження системи контролінгу в діяльність стивідорної компанії супроводжується великою кількістю робіт, які включають організаційні, фінансові, економічні, матеріально-технічні та інші аспекти, а також визначення об'єктів контролінгу: ресурси, витрати, господарські процеси, види діяльності, фінансовий стан та ефективність.

На теперішній час дослідження у напрямку практичної реалізації роботи системи контролінгу як для підприємств взагалі, так і для стивідорної компанії, зокрема, потребують формування базисних основ стосовно специфіки використання наявних ресурсів. У зв'язку з цим, доцільним $\epsilon$ оцінка та пошук резервів ефективності використання ресурсів для отримання більшого ефекту при виконанні плану та своєчасного реагування на можливі відхилення фактичних показників від планових.

Метою статті $\epsilon$ визначення алгоритму оцінки та складу ключових показників ефективності використання ресурсів стивідорної компанії в системі контролінгу.

Виклад основного матеріалу дослідження. В Україні інтерес до контролінгу став проявлятися на початку 90х років, коли були зроблені спроби створити систему управлінського обліку, синхронізувавши іii зі стратегічним й оперативним плануванням. Спочатку такі

Вісник економіки транспорту і промисловості № 67, 2019 
спроби були зроблені в банківській діяльності, а подальше розвиток системи контролінгу відбувся на промислових підприємствах. Темпи розвитку контролінгу в Україні достатньо повільні, при цьому теоретичні аспекти обгрунтування впровадження системи контролінгу обговорюються дуже активно.

Наукові підходи до трактування сутності поняття «контролінг» в різних літературних джерелах суттєво відрізняються. При цьому, основоположними елементами даної категорії повинні бути: системне спостереження; аналізування; планування (бюджетування); прогнозування; контроль (моніторинг) як установлених показників, так і виявлених фактичних відхилень; регулювання виявлених відхилень; підвищення ефективності прийняття управлінських рішень на основі комплексу заходів контролінгу.

Різноманітність підходів до трактування терміну «контролінг» та не визначення даної категорії на законодавчому рівні дозволяє інтерпретувати дану категорію в залежності від галузевої приналежності підприємства, форми власності, організаційної структури та особливостей використання методів аналізу та прогнозування. Крім того, контролінг інтегрує окремі елементи функції управління (облік, аналіз, контроль, планування).

В даному досліджені контролінг будемо розглядати як систему, направлену на формування цільового комплексу заходів щодо досягнення головної мети підприємства - оптимізації фінансового результату через максимізацію прибутку при зберіганні власного капіталу, прибутковості та необхідної ліквідності, а також ефективності використання наявних ресурсів.

Успішна реалізація контролінгу неможлива без участі керівництва, при цьому, співробітники також повинні усвідомлювати всю значимість впровадження оперативного контролінгу, який базується на релевантній інформації, що необхідна для прийняття оптимальних управлінських рішень по різним аспектам діяльності підприємства.

Контролінг реалізується у співпраці менеджерів і контролерів, як і було описано в «класичної» моделі Альбрехта Дайлен (рис. 1).

Контролери надають менеджерам широку підтримку - розвантажують менеджера, переймаючи частину його обов'язків (наприклад, організація процесів планування або надання інформаціі); обмежують менеджера, не допускаючи прийняття ним неекономічних рішень у власних цілях або інтересах функціонального підрозділу. Дана підтримка, у тому числі, спрямована на підвищення ефективності використання всіх видів ресурсів, які має у своєму розпорядженні підприємство.

Ресурси - це керовані чинники виробництва, які володіють вартісними властивостями i перетворюючими можливостями, необхідні для забезпечення функціонування i розвитку виробничих процесів з метою досягнення запланованих результатів [13, с. 173].

До ресурсів, як об'єкту контролінгу, відносяться: трудові, матеріальні, фінансові, інформаційні та інноваційні. Взаємодія всіх видів ресурсів проявляється в забезпеченні стабільного розвитку компанії та підвищення ефективності їх використання в процесі здійснення діяльності.

При досліджені ресурсів стивідорної компанії необхідно враховувати специфіку iï діяльності, яка «пов'язана, перш за все, з тим, що іiі продукцією $є$ послуга, яку не можна зберігати та накопичувати, вона не має доданої вартості, а характеризується тільки підвищенням споживчої вартості товарів, що перевантажуються, на яку собівартість перевантаження впливає не прямо, як на додану вартість (через збільшення прибутку), а опосередковано через конкурентну ціну товару у місті продажу» [14, с. 137].

Вісник економіки транспорту і промисловості № 67, 2019 


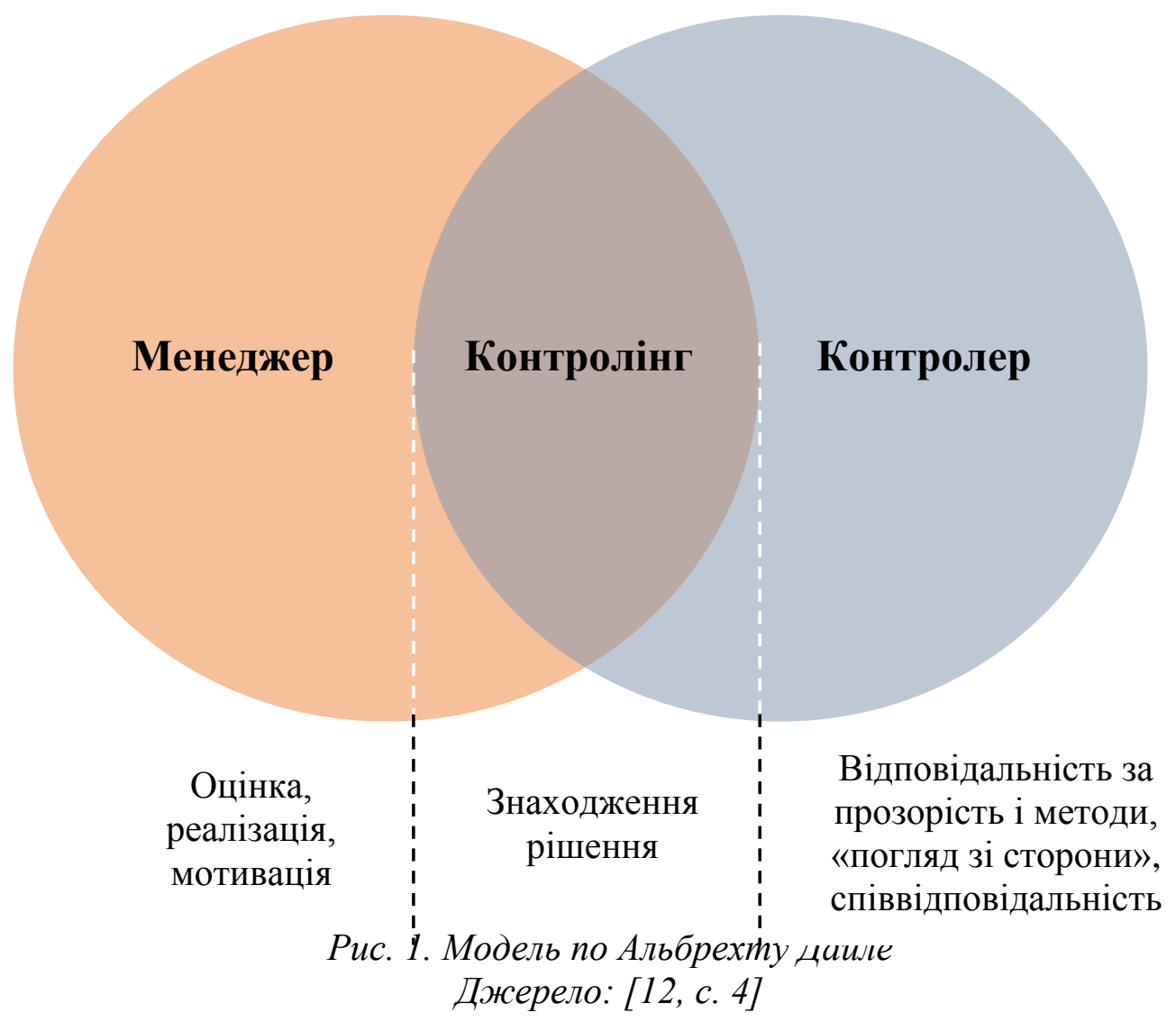

Крім того, стивідорна діяльність охоплює весь перелік комплексу вантажнорозвантажувальних робіт як на судні, так i на причалах та інших об'єктах портової інфраструктури, включаючи складські операції та накопичення партій вантажів, що відрізняє дану діяльність від інших видів. У відповідності до цих особливостей контролінг, як управлінська технологія, є складним та трудомістким процесом, а весь комплекс об'єктів контролінгу стивідорної діяльності повинен бути охоплений його різними формами в залежності від рівня ризику:

- стивідорна компанія отримує або формує i використовує значиму i якісну інформацію для підтримки i функціонування контролінгу;

- стивідорна компанія здійснює внутрішній обмін інформацією, включаючи інформацію про цілі та обов'язки в області контролінгу, яка необхідна для його функціонування;
- стивідорна компанія здійснює обмін інформацією 3 зовнішніми сторонами 3 питань, які впливають на функціонування системи контролінгу.

Розглянемо більш детально об'єкти контролінгу на прикладі функціонування стивідорної компанії.

Трудові ресурси або персонал порту - це сукупність постійних працівників, які отримали необхідну професійну підготовку і (або) мають досвід практичної діяльності. Крім постійних працівників у діяльності порту або його окремих структурних підрозділів беруть участь інші працездатні особи на основі тимчасових трудових договорів (контрактів) [15, с. 337].

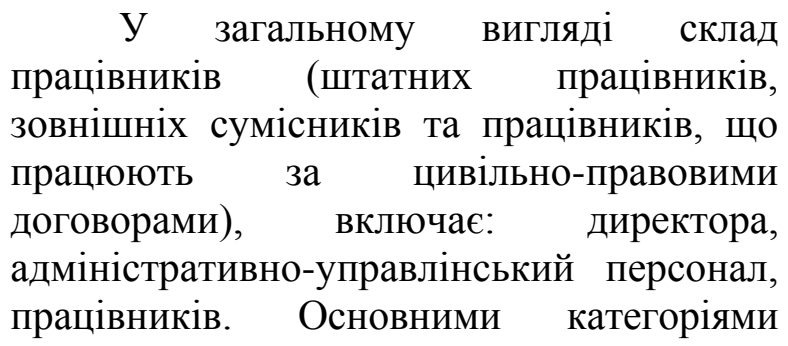


працівників у стивідорній компанії $\epsilon$ інженерно-технічний персонал та робочі, у тому числі докери-механізатори, які поділяються на чотири категорії.

Складний характер виробничих процесів стивідорної компанії вимагає високого професіоналізму фахівців, задіяних в процесі організації та здійснення стивідорних операцій, тобто наявність у них спеціальних знань та навиків (наприклад, термінальні роботи стафірування контейнера, сюрвєйєрські послуги - інспекції кількості та якості вантажів в трюмах суден).

Матеріальні ресурси стивідорної компанії не приймають участь у створенні готової продукції у вигляді товарноматеріальних цінностей. До їх складу відносяться виробничі запаси (паливо, пально-мастильні матеріали, малоцінні та швидкопсувні предмети). Оцінка стану запасів важлива з точки зору запобігання їх надлишкової величини, відволікання оборотних активів та збільшення ефективності їх використання.

Фінансові ресурси стивідорної компанії, як i iнших підприємств, $\epsilon$ сукупністю всіх видів фінансових активів, що знаходяться у розпорядженні компанії. 3 позиції особливостей формування фінансових ресурсів стивідорної компанії необхідно зазначити наявність поточних рахунків в іноземній валюті, які, як правило, домінують у структурі грошових коштів. При формуванні фінансового плану всі фінансові показники закладаються через прогнозний курс долару, а при здійсненні розрахунків даний курс не завжди відповідає прогнозованому. Тому досить актуальним $є$ фактор стабільності національної валюти та курсу іноземної валюти, що напряму впливає на курсові різниці та здійснення фінансової діяльності стивідорної компанії.

Інформаційні ресурси дозволяють оцінити характер інформації про підприємство та зовнішнє середовище, можливість її поповнення чи підвищення достовірності та подані у формі, придатній для збирання, реалізації та відтворення.

Відповідно до сучасних вимог, інформаційне забезпечення дозволяє зменшувати час, необхідний для підготовки й обробки інформації щодо виробничих процесів. Адекватне інформаційне забезпечення дає можливість відповідати на запити клієнтури стивідорної компанії в режимі реального часу.

В системі контролінгу інформація повинна бути достовірною, повною, доступною для порівняння, своєчасною, а також релевантною - для швидкого прийняття управлінських рішень. Своєчасно одержані і використані дані можуть бути основою, як для аналізу результатів звітного періоду, так i для прогнозування рівнів показників у майбутньому.

Інноваційні ресурси стивідорної компанії набувають все більшого значення. Інновації виступають у вигляді нових технологій, видів продукції i послуг, організаційно-технічних i соціальноекономічних рішень управлінського, виробничого, фінансового, комерційного або іншого характеру, що сприяє зростанню результативності певного виду діяльності.

Важливу роль мають технології, які використовуються компанією, наявність конкурентоспроможних ідей та сукупності знань про використання або удосконалення обладнання, які забезпечують навантажувально-розвантажувальні роботи (НРР), наукові розробки та ін.

Впровадження інновацій вимагає певної фінансової підтримки інвестиційних ресурсів, які характеризують інвестиційні можливості стивідорної компанії та формуються за рахунок власних та залучених коштів, наприклад, на умовах кредиту 3 урахуванням можливостей його забезпечення й погашення.

Головне джерело коштів, що формують прибуток, це - виручка від

Вісник економіки транспорту і промисловості № 67, 2019 
реалізації робіт (послуг) стивідорної компанії, яка формується за рахунок чистого доходу від реалізації, інших операційних доходів, інших фінансових доходів (відсотки по депозитним рахункам), інших доходів. В основі формування виручки стивідорної компанії лежить виручка у вигляді доходів від стивідорних послуг.

Іншим основним фактором, що впливає на розмір фінансового результату у вигляді прибутку $\epsilon$ витрати, які включають: собівартість реалізації, адміністративні витрати, витрати на збут, інші операційні витрати, фінансові витрати, інші витрати, витрати з податку на прибуток. Для стивідорної компанії особливістю формування витрат на збут $\epsilon$ відсутність транспортних витрат, витрат на зберігання та упакування. Здебільшого, дані витрати складаються 3 витрат на рекламу.

В системі контролінгу оцінка ресурсів компанії проводиться на базі КРI (Key Performance Indicators - ключеві показники ефективності). Використання показників КРІ дозволяє критично оцінити продуктивність, оперативність, якість або витрати компанії. Використовуючи рекомендовані KPI, можна оцінити ефективність процесу, зробити висновки щодо потенціалу та отримати рекомендації для необхідних змін.

В процесі вибору показників можуть використовуватися фінансові та нефінансові показники KPI, які для кожного процесу дають можливість всебічного вимірювання ефективності. Так, «вимірювання ефективності процесів контролінгу виходить далеко за рамки досягнутої фінансової оцінки, оскільки вона забезпечує прозорість не лише з точки зору фінансової, але й 3 точки зору ефективності. Цілі, пов'язані з процесом, часто не просто спрямовані на максимізацію або мінімізацію, наприклад, мінімізація використаних ресурсів може призвести до проблем з якістю (наприклад, збільшення ліміту для початку інвестиційної оцінки). Максимізація наявних ресурсів не має сенсу через закон зменшення граничної корисності (наприклад, розширення можливостей організації-контролера 3 метою особистої та інтенсивної підтримки наступних організаційних підрозділів)» [16, с. 16].

Згідно «Керівництво для вимірювання ефективності в управлінні процесами» виділяють наступні типи КРI: абсолютні та відносні; кількісні та якісні; орієнтовані на вхід та вихід чи на ефект [16, c. 17].

Відносні KРI, як правило, мають перевагу, придатні для цілей порівняльної оцінки. Для цілей контролінгу відносне порівняння використання ресурсів різних компаній більш доцільно, ніж порівняння ресурсів у абсолютному значенні. Кількісні показники, які базуються на основі чітко вимірюваних факторів, таких як витрати та час, виміряються більш доступно ніж якісні показники наприклад, задоволення.

$$
\text { Вимірювання параметрів, }
$$
орієнтованих на вхід та вихід ускладнено наявністю непрямого впливу факторів на результативний показник чи прояву даного впливу через визначений період. Так, витрати на підвищення кваліфікації та перепідготовку кадрів, які понесені у звітному періоді, окупляться у майбутніх періодах у вигляді, наприклад, підвищення продуктивності праці; витрати на аудиторські послуги дозволять у майбутньому запобігти помилок при складанні фінансової звітності та ін. Оцінка таких параметрів є складною, потребує збір великої кількості інформації та не завжди виправдана 3 позиції співвідношення витрат на проведення такої оцінки та отриманого результату. Більш того, відволікання часу на проведення такого аналізу порушує завдання контролінгу забезпечення раціональності управлінського процесу.

При обгрунтуванні системи кількісних та якісних показників необхідно провести ретельний відбір KPI, які підлягають аналізу з врахуванням специфіки, видів i

Вісник економіки транспорту і промисловості № 67, 2019 
масштабів діяльності компанії, іiі правової форми та організаційної структури.

Оцінку KPI доцільно проводити за алгоритмом - послідовністю дій, виконання яких призведе до вирішення поставленого завдання в системі контролінгу орієнтувати управлінський процес на досягнення поточних та стратегічних цілей компанії з метою оптимізації фінансового результату (рис. 2).

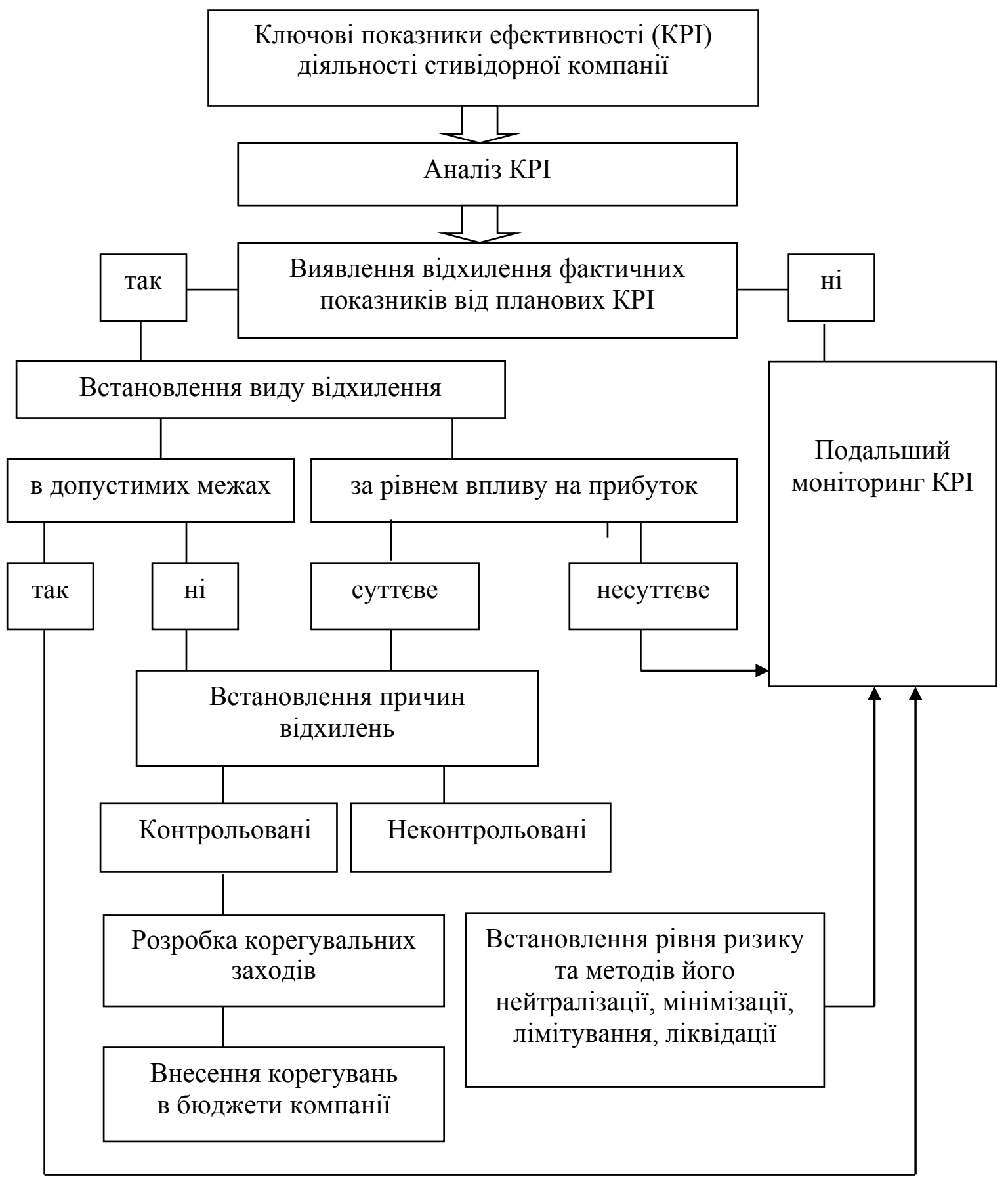

Рис. 2. Алгоритм оцінки ключових показників ефективності використання ресурсів компанії в системі контролінгу

Джерело: розробка авторів

Вісник економіки транспорту і промисловості № 67, 2019 
Наведений алгоритм направлений на виконання наступних функцій контролінгу:

- обліково-контрольної - зіставленні планових та фактичних показників для виміру і оцінки ступеню досягнення мети, встановлювання допустимих меж відхилень від параметрів, що були задані, визначення причин відхилень та розробка пропозицій по їхньому усуненню;

- превентивності - попередження ризику, недопущення або запобігання виникненню несприятливого (кризового) стану об'єкта управління, в нашому випадку - стивідорної компанії.

Процес виконання наведеного на рис. 2 алгоритму враховує наявність різного виду відхилень, серед яких важливого значення мають суттєві відхилення - відносні значимі відхилення в контексті впливу на прибуток, які включають кількісні та якісні фактори (наприклад, величина, характер, ефект, доречність і наслідки).

При встановлені причин відхилень виділяють контрольовані та неконтрольовані причини. Контрольовані причини напряму пов'язані з факторами внутрішнього характеру діяльності компанії - помилки при плануванні, використання недоречних методів планування, недостатністю інформації та ін. Неконтрольовані причини пов'язані 3 проявом факторів зовнішнього середовища: рівень розвитку НТП), вплив міжнародного ринку товарів, вплив інфляції, рівень зайнятості, стабільність національної валюти, законодавство країни, урядові постанови, укази президента, відношення до підприємства різних груп населення, можливість проникнення на ринок, розподіл сегментів, перспектива розвитку ринку та його структури, конкуренти - умови , що домінують на ринку товарів, можливість співіснування, тощо.

Неконтрольовані причини потребують встановлення рівня ризику та методів його нейтралізації, мінімізації, лімітування чи ліквідації. Керівництво компанії вибирає метод реагування на ризик, розробляючи ряд заходів, направлених на доведення виявленого ризику у відповідність 3 допустимим рівнем. Оцінивши відповідні ризики, керівництво визначає, яким чином на них реагувати, тобто знизити ймовірність їх настання у подальшому.

Наведений алгоритм може використовуватися для будь-якої компанії та відрізняється лише набором КРІ. Для оцінки ефективності використання ресурсів стивідорної компанії пропонуються КРІ, наведені у таблиці 1.

Таблиия 1

Ключові показники ефективності використання ресурсів стивідорної компанії в системі контролінгу

\begin{tabular}{|c|c|}
\hline Напрямок оцінки & Показники \\
\hline 1 & 2 \\
\hline \multicolumn{2}{|r|}{ Трудові ресурси } \\
\hline ефективність праці & продуктивність праці у натуральному та грошовому вимірі \\
\hline $\begin{array}{l}\text { ефективність } \\
\text { кадрової політики }\end{array}$ & освітній рівень працівників, коефіцієнт стабільності кадрів \\
\hline $\begin{array}{l}\text { ефективність роботи } \\
\text { управлінського } \\
\text { персоналу }\end{array}$ & $\begin{array}{l}\text { рентабельність витрат на управління компанією (підрозділом), } \\
\text { рентабельність витрат на залучення виконавців до прийняття } \\
\text { управлінських рішень }\end{array}$ \\
\hline \multicolumn{2}{|r|}{ Матеріальні ресурси } \\
\hline $\begin{array}{l}\text { ефективність } \\
\text { використання }\end{array}$ & $\begin{array}{l}\text { витрати палива і енергії на } 1 \text { грн. чистої портової продукції, } \\
\text { економія матеріальних витрат, оборотність та тривалість } \\
\text { обороту паливо-енергетичних ресурсів }\end{array}$ \\
\hline
\end{tabular}

Вісник економіки транспорту і промисловості № 67, 2019 


\begin{tabular}{|c|c|}
\hline \multicolumn{2}{|r|}{ Продовження табл. 1} \\
\hline 1 & $x^{2}$ \\
\hline \multicolumn{2}{|r|}{ Фінансові ресурси } \\
\hline $\begin{array}{l}\text { комплексна оцінка } \\
\text { ефективності } \\
\text { використання } \\
\text { фінансових ресурсів }\end{array}$ & $\begin{array}{l}\text { коефіцієнт економічної ефективності використання фінансових } \\
\text { ресурсів, коефіцієнт підвищення економічної ефективності } \\
\text { використання фінансових ресурсів, коефіцієнт оптимальної } \\
\text { ефективності використання фінансових ресурсів }\end{array}$ \\
\hline коефіцієнти зміни & $\begin{array}{l}\text { обсягів вантажопереробки, доходів та витрат (за видами } \\
\text { діяльності), прибутку (валового, від операційної діяльності, } \\
\text { чистого), собівартості переробки } 1 \text { т вантажу, прогнозного } \\
\text { курсу долару }\end{array}$ \\
\hline $\begin{array}{l}\text { ість } \\
\text { х витрат }\end{array}$ & $\begin{array}{l}\text { рентабельність НРР, рентабельність робіт та послуг, } \\
\text { рентабельність операційної діяльності, ефективність витрат за } \\
\text { оренду причалу, ефективність витрат на енергоресурси }\end{array}$ \\
\hline $\begin{array}{l}\text { рівень } \\
\text { послугомісткості }\end{array}$ & $\begin{array}{l}\text { місткість витрат на НРР, місткість портових зборів, що } \\
\text { сплачуються на користь стивідорної компанії згідно до } \\
\text { законодавства, місткість витрат на інші види послуг }\end{array}$ \\
\hline $\begin{array}{l}\text { ність } \\
\text { гя та } \\
\text { гання }\end{array}$ & $\begin{array}{l}\text { рентабельність сукупних фінансових ресурсів, рентабельність } \\
\text { власного капіталу, рентабельність позикових коштів, } \\
\text { оборотність та тривалість обороту сукупних фінансових } \\
\text { ресурсів, власного капіталу та позикових коштів }\end{array}$ \\
\hline Напрямок оцінки & Показники \\
\hline ий стан & $\begin{array}{l}\text { коефіцієнт автономії, коефіцієнти абсолютної, швидкої та } \\
\text { загальної ліквідності, оборотність та тривалість обороту } \\
\text { окремих статей балансу, коефіцієнт відволікання грошових } \\
\text { коштів у дебіторську заборгованість, коефіцієнт прихованих } \\
\text { витрат, мультиплікатор капіталу }\end{array}$ \\
\hline \multicolumn{2}{|r|}{ Інформаційні ресурси } \\
\hline $\begin{array}{l}\text { ефек } \\
\text { вико }\end{array}$ & $\begin{array}{l}\text { ефективність інформаційної системи, частка витрат на відділ } \\
\text { автоматизованих систем управління в собівартості портової } \\
\text { продукції, ефективність точності та суперечливості інформації }\end{array}$ \\
\hline капі & 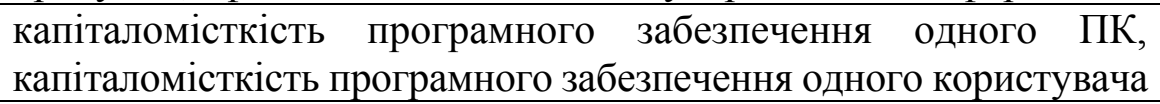 \\
\hline \multicolumn{2}{|r|}{ Інноваційні ресурси } \\
\hline $\begin{array}{l}\text { ефективність } \\
\text { інноваційних } \\
\text { заходів } \\
\end{array}$ & нтабельність інног \\
\hline $\begin{array}{l}\text { ефект інноваційних } \\
\text { заходів }\end{array}$ & $\begin{array}{l}\text { відносна економія собівартості, приріст прибутку, підвищення } \\
\text { конкурентоспроможності компанії на ринку, ефект впливу } \\
\text { інновації на обсяги споживання певного виду ресурсу, ефект від } \\
\text { підвищення продуктивності, зниження викидів у навколишнє } \\
\text { середовище }\end{array}$ \\
\hline \multicolumn{2}{|r|}{ Інвестиційні ресурси } \\
\hline $\begin{array}{l}\text { ефективність } \\
\text { окремих проектів }\end{array}$ & $\begin{array}{l}\text { чиста теперішня вартість проекту, внутрішня норма } \\
\text { рентабельності, індекс прибутковості, коефіцієнт вигід/витрат, } \\
\text { термін окупності інвестицій }\end{array}$ \\
\hline $\begin{array}{l}\text { інвестиційна } \\
\text { привабливість }\end{array}$ & $\begin{array}{l}\text { рентабельність EBITDA, ефективність надійності прогнозу } \\
\text { витрат та прибутку }\end{array}$ \\
\hline
\end{tabular}

Джерело: Складено з використанням [10, 14, 16-19] та доповнено

Вісник економіки транспорту і промисловості № 67, 2019 
Застосування наведених ключових показників ефективності використання ресурсів базується на аналізі і діагностиці впливу процесів і факторів у зв'язку 3 господарською діяльністю та дозволить організувати безперервний процес спостереження i зіставлення планових i фактичних параметрів стивідорної компанії для відстеженням динаміки змін за кожним видом ресурсів 3 метою підвищення ефективності їх використання.

Таким чином, контролінг ресурсів стивідорної компанії представляє собою складне та комплексне завдання, направлене на економічне зростання та ефективність розвитку. Реалізація цього завдання залежить від оптимально скоординованої роботи всіх працівників підприємства на усіх етапах функціонування, починаючи від розроблення стратегії підприємства, закінчуючи впровадженням окремих програм розвитку.

Висновок. В досліджені розглянуті об'єкти контролінгу на прикладі функціонування стивідорної компанії, визначені особливості формування іiі трудових, матеріальних, фінансових, інформаційних та інноваційних. Запропоновано алгоритм оцінки ключових показників ефективності використання ресурсів компанії в системі контролінгу, який враховує наявність різного виду відхилень та направлений на виконання основних функцій контролінгу: обліковоконтрольної (зіставленні планових та фактичних показників) та превентивності (попередження ризику). Рекомендовано перелік ключових показників ефективності використання ресурсів стивідорної компанії, які враховують особливості іiі функціонування та, наряду з традиційними показниками ефективності діяльності компанії, включають оцінку ефективності використання енергоресурсів, як суттєвої статті витрат стивідорної компанії, рівня послугомісткості та ефекту впливу інновації на обсяги споживання певного виду ресурсу, в тому числі зниження викидів у навколишнє середовище. Використання запропонованих КРI базується на аналізі і діагностиці впливу процесів i факторів у зв'язку 3 господарською діяльністю та дозволить організувати безперервний процес спостереження i реєстрації планових i фактичних параметрів стивідорної компанії для відстеженням динаміки змін за кожним видом ресурсів 3 метою підвищення ефективності їх використання.

\section{ПЕРЕЛІК ВИКОРИСТАНИХ ДЖЕРЕЛ}

1. Becker W. Funktionsprinzipien des Controlling. Zeitschrift fuer Betriebswirtschaft. 60, 295318.

2. Манн Р., Майер Э. Контроллинг для начинающих. М.: Финансы и статистика, 1995. 304 с.

3. Хан Д., Хунгенберг Х. Планирование и контроль: стоимостноориентированные концепции контроллинга. М.: Финансы и статистика, $2005.925 \mathrm{c}$

4. International Group of Controlling: official website. URL: https://www.igccontrolling.org/

5. Артамонова М.Ю. Методы оценки эффективности работы службы контроллинга в морских портах. Вестник государственного университета морского u речного флота им. адмирала С.О. Макарова. 2010. С. 131-136.

6. Потай І.Ю. Контролінг у стратегічному плануванні розвитку морських портів України. Збірник наукових праць Національного університету кораблебудування. 2015. № 6 (462). С. 109118. DOI 10.15589/jnn20150617

7. Будник В.А., Шкурко Є.Л. Контролінг тарифів на перевалку вантажів у морських портах України. Проблеми економіки. 2014. № 2. С. 100-107.

8. Рябоволенко Н.В. Контролінг портових зборів у морських портах України. Проблеми економіки транспорту. 2017. Вип. 14. С. 88-96.

Вісник економіки транспорту і промисловості № 67, 2019 
9. Yarovaya N.V., Vorkunova O.V., Ryabovolenko N.V. Controlling coordination instrument for managerial decision-making on pricing. Modern directions of theoretical and applied researches. 2014. P. 7-11. URL: https://www.sworld.com.ua/konfer34/424.pdf

10. Онешко C.B., Попов I.I. Контролінг економічної безпеки підприємств портової діяльності. Вісник економіки транспорту $і$ промисловості. 2019. №65. C. 39-51. DOI: https://doi.org/10.18664/338.47:338.45.v0i65 .155861

11. Oneshko S., Ilchenko S. Financial monitoring of the port industry companies on the basis of risk-oriented approach. Investment Management and Financial Innovations. Volume 14, Issue \#1, 2017. pp. 191-199. DOI: 10.21511/imfi.14(1-1).2017.05

12. Базовые положения Международного

Объединения

Контроллеров и Международной Группы Контроллинга. URL: https://www.igccontrolling.org/fileadmin/pdf/ICV_IGC_Valu epaper_RU.pdf

13. Михайловська О.В. Операційний менеджмент: навчальний посібник. К.: Кондор, 2008. 550 с.

14. Бойко М.О. Сучасні тенденції розвитку стивідорних компаній України. Вісник економіки транспорту $i$ промисловості. 2018. № 63. С. 133-144.

15. Жихарева В.В., Котлубай А.М., Кибик О.Н. и др. Экономика морского транспорта: учебник. Харьков: «БУРУН КНИГА», 2012. 480 c.

16. Controlling Process KPIs. A Guideline for Measuring Performance in Controlling Processes. Haufe Gruppe, Freiburg. München. 2012. 80 p.

17. Бойко М.О., Опря В.О., Балан Я.О. Підхід до формування системи показників оцінки економічного потенціалу підприємств портової діяльності. Розвиток методів господарювання та управління на транспорті. 2018. №4(65). С. 59-72.
18. Гвоздєй Н.I., Бондарук I.C., Вінницька О.А. Оцінка ефективності використання фінансових ресурсів підприємства. Економічний аналіз. 2018. Т. 28. №1. C. 216-222.

19. Ковальчук В.В. Механізм управління інформаційними ресурсами промислових підприємств: автореф. дис. ... канд. екон. наук спец. 08.06.01. Хмельницький, 2006. 20 с.

\section{REFERENCES}

1. Becker W

(1990)

Funktionsprinzipien des Controlling. Zeitschrift fuer Betriebswirtschaft. 60, 295318. (in English)

2. Mann R., Mayer E. Kontrolling dlya nachinayuschih [Controlling for beginners]. M.: Finansyi i statistika, 1995. 304 p. (in Russian)

3. Han D., Hungenberg H. Planirovanie i kontrol: stoimostno-orientirovannyie kontseptsii kontrollinga [Planning and control: value-oriented concepts of controlling]. M.: Finansyi i statistika, 2005. 925 p. (in Russian)

4. International Group of Controlling: official website. URL: https://www.igccontrolling.org/ (in English)

5. Artamonova M.Yu. Metodyi otsenki effektivnosti rabotyi sluzhbyi kontrollinga $\mathrm{v}$ morskih portah [Methods for assessing the effectiveness of the controlling service in seaports]. Bulletin of the State University of the Sea and River Fleet. Admiral S.O. Makarova. 2010. pp. 131-136. (in Russian)

6. Potai I.Iu. Kontrolinh u stratehichnomu planuvanni rozvytku morskykh portiv Ukrainy [Controlling of strategic plan development of marine ports of Ukraine]. Collection of scientific works of the National University of Shipbuilding. 2015. № 6 (462). pp. 109-118. DOI 10.15589/jnn20150617 (in Ukrainian)

7. Budnyk V.A., Shkurko Ye.L. Kontrolinh taryfiv na perevalku vantazhiv u morskykh portakh Ukrainy [Controlling of tariffs for transshipment of cargo in the seaports of Ukraine]. Problems of economy.

Вісник економіки транспорту і промисловості № 67, 2019 
2014. № 2. pp. 100-107. (in Ukrainian)

8. Riabovolenko N.V. Kontrolinh portovykh zboriv $\mathrm{u}$ morskykh portakh Ukrainy [Controlling of port charges in the seaports of Ukraine]. Problems of Transport Economics. 2017. Вип. 14. pp. 88-96. (in Ukrainian)

9. Yarovaya N.V., Vorkunova O.V., Ryabovolenko N.V. Controlling coordination instrument for managerial decision-making on pricing. Modern directions of theoretical and applied researches, 2014. P. 7-11. URL: https://www.sworld.com.ua/konfer34/424.pdf (in English)

10. Oneshko S.V., Popov I.I. Kontrolinh ekonomichnoi bezpeky pidpryiemstv portovoi diialnosti [Controlling the economic security of port businesses]. Bulletin of Economics of Transport and Industry. 2019. № 65. pp. 39-51. DOI: https://doi.org/10.18664/338.47:338.45.v0i65. 155861 (in Ukrainian)

11. Oneshko S., Ilchenko S. Financial monitoring of the port industry companies on the basis of risk-oriented approach. Investment Management and Financial Innovations. Volume 14, Issue \#1, 2017. pp. 191-199. DOI: 10.21511/imfi.14(1-1).2017.05 (in English)
12.
Bazovyie
polozheniya

Mezhdunarodnogo Ob'edineniya Kontrollerov

i Mezhdunarodnoy Gruppyi Kontrollinga [Basic Provisions of the International Controllers Association and the International Controlling Group]. URL: https://www.igccontrolling.org/fileadmin/pdf/ICV_IGC_Valu epaper_RU.pdf (in Russian)

13. Mykhailovska O.V. Operatsiinyi menedzhment: navchalnyi posibnyk
[Operational management: a textbook]. K .: Condor, 2008. 550 p. (in Ukrainian)

14. Boiko M.O. Suchasni tendentsii rozvytku styvidornykh kompanii Ukrainy [Current trends of stevedoring companies in Ukraine]. Bulletin of Economics of Transport and Industry. 2018. № 63. pp. 133-144. (in Ukrainian)

15. Zhihareva V.V., Kotlubay A.M., Kibik O.N. i dr. Ekonomika morskogo transporta: uchebnik [Economics of Maritime Transport: A Textbook]. Harkov: «BURUN KNIGA», 2012. 480 c. (in Russian)

16. Controlling Process KPIs. A Guideline for Measuring Performance in Controlling Processes. Haufe Gruppe, Freiburg. München. 2012. 80 p. (in English)

17. Boiko M.O., Opria V.O., Balan Ya.O. Pidkhid do formuvannia systemy pokaznykiv otsinky ekonomichnoho potentsialu pidpryiemstv portovoi diialnosti [Approach to the formation of a system of indicators for assessing the economic potential of port enterprises]. Development of transport management and management methods. 2018. №4(65). pp. 59-72. (in Ukrainian)

18. Hvozdiei N.I., Bondaruk I.S., Vinnytska O.A. Otsinka efektyvnosti vykorystannia finansovykh resursiv pidpryiemstva [Assessment of efficiency of use of financial resources of the enterprise]. Economic analysis. 2018. T. 28. №1. pp. 216222. (in Ukrainian)

19. Kovalchuk V.V. Mekhanizm upravlinnia informatsiinymy resursamy promyslovykh pidpryiemstv [The mechanism of management of information resources of industrial enterprises]: author's abstract. diss. ... Ph.D. specialist 08.06.01. Khmelnytskyi, 2006. 20 p. (in Ukrainian) 